\title{
SOIL FAUNA AND LEAF LITTER DECOMPOSITION IN DIFFERENT SUCCESSIONAL STAGES OF A SUBMOUNTAINOUS SEASONAL SEMIDECIDUOUS FOREST
}

\author{
Luciano de Oliveira Toledo ${ }^{1}$, Rodrigo Camara ${ }^{2}$, Carlos Eduardo Gabriel Menezes ${ }^{3}$, Marcos Gervasio Pereira ${ }^{4 *}$ \\ ${ }^{1 *}$ Instituto Federal de Educação, Ciência e Tecnologia do Espírito Santo (IFES), Campus Santa Teresa, São João de Petrópolis, Espírito \\ Santo, Brasil - luctoledo@gmail.com \\ ${ }^{2}$ Universidade Federal Rural do Rio de Janeiro (UFRRJ), Programa de Pós-Graduação em Ciências Ambientais e Florestais (PPGCAF), \\ Seropédica, Rio de Janeiro, Brasil - rcamara73@gmail.com \\ ${ }^{3}$ Instituto Federal de Educação, Ciência e Tecnologia do Rio de Janeiro (IFRJ), Pinheiral, Rio de Janeiro, Brasil - carlos.menezes@ifrj.edu.br \\ ${ }^{4}$ Universidade Federal Rural do Rio de Janeiro (UFRRJ), Departamento de Solos, Seropédica, Rio de Janeiro, Brasil - \\ mgervasiopereira01@gmail.com
}

Received for publication: 27/09/2019 - Accepted for publication: 16/11/2020

\begin{abstract}
Resumo
Fauna do solo e decomposição de serapilheira foliar em diferentes estágios sucessionais de Floresta Estacional Semidecidual Submontana. Em florestas tropicais, o estágio de sucessão ecológica influencia a ciclagem de nutrientes. Este estudo teve como objetivo analisar a estrutura e composição da comunidade da fauna do solo, e a decomposição da serapilheira foliar em fragmentos de Floresta Estacional Semidecidual em estágios sucessionais intermediário e avançado (ISF e LSF, respectivamente). Utilizamos uma armação quadrada de metal para coletar 10 amostras da camada de serapilheira e do solo superficial (profundidade de 0,00-0,05 m) em cada área, nas estações chuvosa e seca. Os indivíduos da fauna do solo foram então extraídos usando funis de Berlese-Tüllgren modificados. Para a análise da decomposição da serapilheira, 15 sacos contendo $30 \mathrm{~g}$ de folhas senescentes foram aleatoriamente colocados sobre o solo florestal em cada área, na estação seca, e três sacos foram coletados após 60, 90, 120, 150 e 180 dias. Formicidae, Diptera e Coleoptera foram os grupos predominantes, independentemente do estágio sucessional. 16 grupos taxonômicos (classe, ordem ou família) restringiram-se á área de LSF, e nenhum grupo se restringiu à área de ISF. A área de LSF se associou a maiores valores de densidade total, riqueza total, riqueza média, diversidade e densidade de todos os grupos taxonômicos, com a exceção de Collembola e uniformidade, cujos maiores valores ocorreram na área de ISF. O processo de decomposição da serapilheira foliar foi praticamente o mesmo, nas duas áreas.

Palavras-chave: Floresta Atlântica; sucessão ecológica; fauna edáfica; ciclagem de nutrientes.
\end{abstract}

\begin{abstract}
In tropical forests, the stage of ecological succession influences the nutrient cycling. This study aimed to analyze the soil fauna community structure and composition, and leaf litter decomposition in fragments of intermediate-successional and late-successional Submountainous Seasonal Semideciduous Forest (ISF and LSF, respectively). We used a square metal frame to collect 10 samples of the leaf litter layer and topsoil (0.00$0.05 \mathrm{~m}$ depth) from each area in the wet and dry seasons. Soil fauna individuals were then extracted using a modified Berlese-Tüllgren funnel. For analysis of leaf litter decomposition, 15 litter bags containing $30 \mathrm{~g}$ of senescent leaves were randomly placed on the forest floor of each area in the dry season, and three bags were collected after 60, 90, 120, 150, and 180 days. Formicidae, Diptera, and Coleoptera were the predominant groups, regardless of successional stage. 16 taxonomic groups (class, order, or family) were restricted to the LSF area and no group was restricted to the ISF area. The LSF area was associated with greater values of total density, total richness, mean richness, diversity, and density of all of the soil fauna taxonomic groups, with the exception of Collembola and evenness, whose greater values were verified in the ISF area. The process of leaf litter decomposition was almost identical in both areas.
\end{abstract}

Keywords: Atlantic Forest; ecological succession; edaphic fauna; nutrient cycling.

\section{INTRODUCTION}

Ecological succession is the process by which an ecosystem develops over time through directional changes in plant community structure and composition. In general, tropical forests in more advanced stages of succession are composed of tree communities with higher biomass and greater species richness than those found in early- to intermediate-successional forests. Thus, the leaf litter production, which varies according to tree community structure, and nutrient transfer from plants to the soil increase with successional stage (MACHADO et al., 2015a; CAMARA et al., 2018a).

In order for plant litter to enhance soil nutrient availability, it is necessary the litter decomposition; otherwise, nutrients remain entrapped in a thick layer of litter on the soil surface. Menezes et al. (2010), studying

FLORESTA, Curitiba, PR, v. 51, n. 2, p. 429-438, abril/jun 2021.

Toledo, L. O. et.al.

ISSN eletrônico 1982-4688

DOI: $10.5380 /$ rf.v51 i2. 69413 
fragments of Seasonal Semideciduous Forest, observed that late-successional areas had the highest litter decomposition rates, followed by early-successional and intermediate-successional areas. Machado et al. (2015a) also found higher decomposition rates in late-successional Seasonal Semideciduous Forest but reported intermediate decomposition rates in intermediate-successional stages and low decomposition rates in early succession. On the other hand, Mountainous Dense Ombrophilous Forest fragments in early, intermediate, and late succession were not found to differ in litter decomposition rate (VENDRAMI et al., 2012).

These differences in results emphasize the need for further studies to investigate the influence of the ecological succession stage on litter decomposition. For instance, leaf litter chemical composition (CAMARA et al., 2018a) and soil microclimate (MALTA et al., 2012) vary according to the stage of ecological succession, and both influence the activity of the soil fauna. This community plays a direct role in nutrient cycling by facilitating the action of decomposing microorganisms through the fragmentation of litter and also has indirect effects on nutrient dynamics by controlling decomposer populations through predation (CORREIA; ANDRADE, 2008).

The importance of fauna organisms living in the soil-litter interface or in the topsoil (SABU et al., 2011) is illustrated by studies showing that their removal leads to reduced litter decomposition (LECERF, 2017). Some studies analyzed the soil fauna of Atlantic Forest fragments in different successional stages (MACHADO et al., 2015b). However, it has not been possible to draw clear conclusions about the influences of successional stage on the soil fauna community and its relationship with litter decomposition. This study aimed to evaluate the influence of successional stage on the soil fauna and leaf litter decomposition in a Submountainous Seasonal Semideciduous Forest. We hypothesized that soil fauna community structure and composition grows more complex and litter decomposition rates increase as ecological succession progresses.

\section{MATERIAL AND METHODS}

\section{Study area}

The experiment was conducted in Pinheiral, Rio de Janeiro (RJ), Brazil, between latitudes $22^{\circ} 30^{\prime} \mathrm{S}$ and $22^{\circ} 38^{\prime} \mathrm{S}$ and longitudes $43^{\circ} 57^{\prime} \mathrm{W}$ and $44^{\circ} 05^{\prime} \mathrm{W}$ at $420 \mathrm{~m}$ above sea level. According to the Köppen classification, the local climate is Cwa (humid subtropical), with dry winters and hot summers (ALVARES et al., 2013). The average annual temperature is $21{ }^{\circ} \mathrm{C}$, and the average annual rainfall is $1.331 \mathrm{~mm}$. The average monthly temperature and rainfall are highest $\left(24^{\circ} \mathrm{C}\right.$ and $231 \mathrm{~mm}$, respectively) in January and lowest $\left(17.6^{\circ} \mathrm{C}\right.$ and $20 \mathrm{~mm}$, respectively) in July (Figure 1).

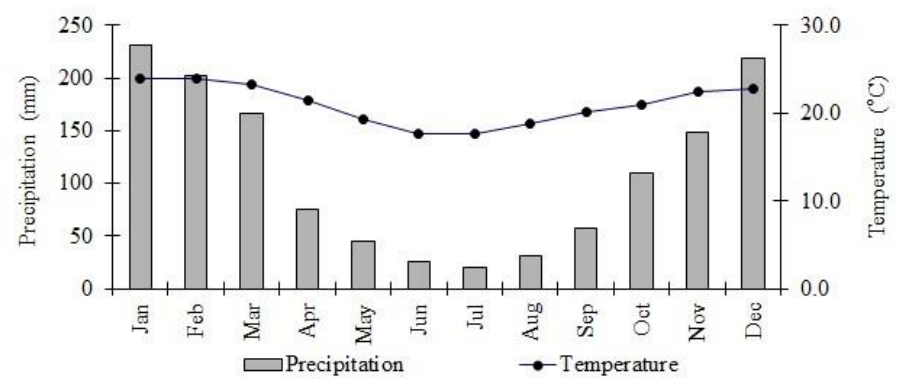

Figure 1. Average monthly temperature and precipitation in Pinheiral, Rio de Janeiro, Brazil. Source: https://pt.climate-data.org/america-do-sul/brasil/rio-de-janeiro/pinheiral-33667/.

Figura 1. Valores médios de temperatura e precipitação mensais em Pinheiral, Rio de Janeiro, Brasil. Fonte: https://pt.climate-data.org/america-do-sul/brasil/rio-de-janeiro/pinheiral-33667/.

Long-term residents of Pinheiral reported that many areas in the municipality were subjected to intensive wood harvesting in the past. In the colonial period, wood logging was replaced by coffee cultivation, and afterward coffee plantations gave way to Brachiaria pastures. The landscape is also composed of natural grasslands formed by Melinis minutiflora P. Beauv., Hyparrhenia rufa (Ness) Stapf., Imperata brasiliensis Trin., Andropogon bicornis L., and Paspalum notatum Flüggé. Nowadays, dairy and beef production is the main economic activity in Pinheiral. This history of land use produced areas at different stages of degradation and regeneration, including rough pastures and secondary forests. Fragments of Atlantic Forest at different stages of natural regeneration are also found amid this landscape mosaic. The original vegetation is Submountainous Seasonal Semideciduous Forest.

This study analyzed two secondary forest areas located on an old farm. The first area is a 20-year-old intermediate-successional forest (ISF) and the second is a 60-year-old late-successional forest (LSF) (BRASIL, 1994). ISF has an arboreal-shrubby, closed-canopy vegetation in the early stages of stratification, understory

FLORESTA, Curitiba, PR, v. 51, n. 2, p. 429-438, abril/jun 2021.

Toledo, L. O. et.al.

ISSN eletrônico 1982-4688

DOI: $10.5380 /$ rf.v51 i2. 69413 
reinitiation, and development of shade-tolerant species. Individuals range in height from 5 to $12 \mathrm{~m}$ and in diameter at breast height from 10 to $20 \mathrm{~cm}$. LSF, on the other hand, has arboreal vegetation, with trees more than $20 \mathrm{~m}$ high and having a mean diameter at breast height of $20 \mathrm{~cm}$. The canopy is relatively uniform and closed, with an understory organized in one or more strata. Bryophytes, epiphytes, and lichens are widely present in LSF but not in ISF. Both areas correspond to an area of 5 ha in the middle-third section of the same hill surrounded by degraded grassland. The soil is Red-Yellow Alic Argisol with low clay activity.

\section{Soil fauna}

In the wet and dry seasons, the leaf litter and 0-5 cm depth soil (topsoil) layers of each area were sampled in 10 random points using a square metal frame for analysis of the soil fauna community. The mean distance between sampling points was about $10 \mathrm{~m}$. In the laboratory, fauna individuals were extracted using a modified Berlese-Tüllgren funnel (GARAY, 1989). Briefly, leaf litter and topsoil samples were placed individually on a galvanized steel screen ( $5 \mathrm{~mm}$ mesh) inside the funnel. A $40 \mathrm{~W}$ lamp was placed over each sample for 15 consecutive days to create a moisture gradient. A $300 \mathrm{~mL}$ glass bottle containing a $3 \%$ acetylsalicylic acid solution was attached to the bottom of the funnel to capture soil fauna individuals. After the 15-day period, the bottles were completed with $70 \%$ alcohol and the contents were transferred to Petri dishes.

We classified the animals into large taxonomic groups (class, order, or family) such as previous studies (GARAY, 1989; SABU et al., 2011; MACHADO et al., 2015b; CAMARA et al., 2018b; FERREIRA et al., 2018) using a stereoscopic microscope. This procedure does not require deep taxonomic knowledge of the high diversity of edaphic animals. Afterwards, we estimated the value of total density (D) and density of taxonomic groups (individuals $\mathrm{m}^{-2}$ ), total richness or number of taxonomic groups $(\mathrm{S})$, mean richness $(\mathrm{Sm})$, evenness (U, Pielou index), diversity (H', Shannon index) (ODUM, 1988), and relative density (\%) of the soil fauna taxonomic groups, based on the sum of individuals extracted from the leaf litter layer and topsoil. The taxonomic groups with a very low relative density $(<3 \%)$ in the soil fauna community were reunited as the group "Others". We calculated the relative density of the soil fauna community (\%) individually extracted from litter layer and topsoil. Due to the high abundance of Formicidae individuals, which exhibit social behavior and may not necessarily indicate their higher occurrence, we also decided to estimate evenness and diversity indices excluding individuals from this group.

Multivariate analyzes were performed with the whole data from the soil fauna community in the absence of Formicidae, using PAST version 2.17c. We performed principal component analysis (PCA) to identify associations between forest areas and soil fauna parameters in each season. For this, we considered the average values of the soil fauna attributes that presented correlation coefficients above $0.70 \%$ with the principal component 1 or principal component 2. Hereafter, a hierarchical cluster analysis based on Bray-Curtis distances and the singlelinkage method was carried out to identify similarities between the areas in the wet and dry seasons.

\section{Leaf litter decomposition}

We randomly collected senescent leaves from the tree canopy of each area, taken to the laboratory, and allowed to dry on a lab bench at room temperature. Then, we added $30 \mathrm{~g}$ of the material to polyvinyl litterbags (25 $\times 25 \times 1.5 \mathrm{~cm}, 4 \mathrm{~mm}$ mesh). We randomly placed 15 bags on the soil surface at each area in the dry season to simulate the natural decomposition of leaf litter. We collected three bags after 60, 90, 120, 150, and 180 days.

After each collection, litterbags were dried in a forced air oven at $65{ }^{\circ} \mathrm{C}$ for $48 \mathrm{~h}$. Subsequently, soil particles, insects, and other organisms were removed, and the remaining material was weighed on an analytical balance $( \pm 0.01 \mathrm{~g})$. The mass loss was calculated by the equation:

$$
\text { Mass loss }(\%)=\left(\frac{\text { Initial weight }}{\text { Final weight }}\right) \times 100
$$

The decay constant $(k)\left(\mathrm{g} \mathrm{g}^{-1}\right.$ day $\left.^{-1}\right)$ was estimated using the exponential decay equation given by Thomas and Asakawa (1993):

$$
X_{t}=X_{0} e^{-k t}
$$

In which $X_{t}$ is the dry weight remaining after $t$ days and $X_{0}$ is the initial dry weight.

The half-life $\left(t_{1 / 2}\right)$, which is the time taken to decompose $50 \%$ of the initial leaf litter dry weight, was calculated using the value of $k$, according to Rezende et al. (1999):

$$
t_{1 / 2}=\frac{\ln (2)}{k}
$$

Decay equations and curves were calculated using SigmaPlot version 12.0 (Systat Software Inc., USA).

FLORESTA, Curitiba, PR, v. 51, n. 2, p. 429-438, abril/jun 2021. 


\section{RESULTS}

\section{Soil fauna}

In the study, 2,730 individuals were captured distributed in 33 taxonomic groups (Table 1). We observed that 13 groups occurred in both areas and climate seasons. However, 16 groups (Chilopoda, Dermaptera, Diplura, Embioptera, Gastropoda, Opilionida, Pauropoda, Plecoptera, Protura, Pseudoscorpionida, Psocoptera, Symphyla, Trichoptera, Thysanoptera, and Thysanura larvae and adults) were restricted to the LSF area, while no group was restricted to the ISF area.

Table 1. Density (individuals $\mathrm{m}^{-2}$ ) and relative density (\%) of the soil fauna taxonomic groups (based on the sum of individuals extracted from the leaf litter layer and topsoil) in intermediate- and late-successional areas of Submountainous Seasonal Semideciduous Forest (ISF and LSF, respectively) in the wet and dry seasons in Pinheiral, Rio de Janeiro, Brazil*.

Tabela 1. Densidade (indivíduos $\mathrm{m}^{-2}$ ) e densidade relativa (\%) de grupos taxonômicos da fauna do solo (com base na soma de indivíduos extraídos da camada de serapilheira e do solo superficial) em áreas de Floresta Estacional Semidecidual Submontana em estágios sucessionais intermediário e avançado (ISF and LSF, respectivamente) nas estações chuvosa e seca em Pinheiral, Rio de Janeiro, Brasil*.

\begin{tabular}{|c|c|c|c|c|c|c|c|c|c|c|}
\hline Taxonomic group & $\begin{array}{l}\text { ISF/ } \\
\text { Wet } \\
\end{array}$ & $\%$ & $\begin{array}{l}\text { ISF/ } \\
\text { Dry }\end{array}$ & $\%$ & $\begin{array}{c}\text { ISF/ } \\
\text { Mean (\%) }\end{array}$ & $\begin{array}{l}\text { LSF/ } \\
\text { Wet }\end{array}$ & $\%$ & $\begin{array}{c}\text { LSF/ } \\
\text { Dry }\end{array}$ & $\%$ & $\begin{array}{c}\text { LSF/ } \\
\text { Mean }(\%)\end{array}$ \\
\hline Araneae & 10 & 3.9 & 10 & 2.7 & 3.2 & 19 & 2.6 & 21 & 1.5 & 1.9 \\
\hline Auchenorrhyncha & 6 & 2.6 & 2 & 0.4 & 1.3 & 10 & 1.3 & 10 & 0.7 & 0.9 \\
\hline Blattaria & 2 & 0.6 & 2 & 0.4 & 0.5 & 6 & 0.9 & 10 & 0.7 & 0.8 \\
\hline Chilopoda & 0 & 0.0 & 0 & 0.0 & 0.0 & 6 & 0.9 & 6 & 0.5 & 0.6 \\
\hline Coleoptera & 8 & 3.2 & 40 & 11.2 & 7.9 & 82 & 10.9 & 24 & 1.7 & 5.0 \\
\hline Coleoptera's larvae & 6 & 2.6 & 5 & 1.3 & 1.9 & 8 & 1.1 & 10 & 0.7 & 0.8 \\
\hline Collembola & 24 & 9.7 & 19 & 5.4 & 7.1 & 13 & 1.7 & 11 & 0.8 & 1.1 \\
\hline Dermaptera & 0 & 0.0 & 0 & 0.0 & 0.0 & 5 & 0.6 & 2 & 0.1 & 0.3 \\
\hline Diplopoda & 2 & 0.6 & 0 & 0.0 & 0.3 & 6 & 0.9 & 6 & 0.5 & 0.6 \\
\hline Diplura & 0 & 0.0 & 0 & 0.0 & 0.0 & 3 & 0.4 & 2 & 0.1 & 0.2 \\
\hline Diptera & 3 & 1.3 & 86 & 24.2 & 14.8 & 22 & 3.0 & 682 & 49.7 & 33.1 \\
\hline Diptera's larvae & 8 & 3.2 & 3 & 0.9 & 1.9 & 10 & 1.3 & 10 & 0.7 & 0.9 \\
\hline Embioptera & 0 & 0.0 & 0 & 0.0 & 0.0 & 5 & 0.6 & 5 & 0.3 & 0.5 \\
\hline Formicidae & 134 & 54.2 & 163 & 45.7 & 49.2 & 435 & 57.9 & 490 & 35.7 & 43.5 \\
\hline Gastropoda & 0 & 0.0 & 0 & 0.0 & 0.0 & 2 & 0.2 & 0 & 0.0 & 0.1 \\
\hline Heteroptera & 6 & 2.6 & 8 & 2.2 & 2.4 & 6 & 0.9 & 10 & 0.7 & 0.8 \\
\hline Hymenoptera & 6 & 2.6 & 2 & 0.4 & 1.3 & 10 & 1.3 & 11 & 0.8 & 1.0 \\
\hline Isopoda & 2 & 0.6 & 2 & 0.4 & 0.5 & 8 & 1.1 & 3 & 0.2 & 0.5 \\
\hline Isoptera & 5 & 1.9 & 2 & 0.4 & 1.1 & 16 & 2.1 & 5 & 0.3 & 1.0 \\
\hline Lepidoptera's larvae & 3 & 1.3 & 2 & 0.4 & 0.8 & 10 & 1.3 & 5 & 0.3 & 0.7 \\
\hline Oligochaeta & 3 & 1.3 & 2 & 0.4 & 0.8 & 6 & 0.9 & 5 & 0.3 & 0.5 \\
\hline Opilionida & 0 & 0.0 & 0 & 0.0 & 0.0 & 6 & 0.9 & 5 & 0.3 & 0.5 \\
\hline Orthoptera & 19 & 7.7 & 11 & 3.1 & 5.0 & 13 & 1.7 & 16 & 1.2 & 1.4 \\
\hline Pauropoda & 0 & 0.0 & 0 & 0.0 & 0.0 & 3 & 0.4 & 2 & 0.1 & 0.2 \\
\hline Plecoptera & 0 & 0.0 & 0 & 0.0 & 0.0 & 5 & 0.6 & 2 & 0.1 & 0.3 \\
\hline Protura & 0 & 0.0 & 0 & 0.0 & 0.0 & 5 & 0.6 & 0 & 0.0 & 0.2 \\
\hline Pseudoscorpionida & 0 & 0.0 & 0 & 0.0 & 0.0 & 5 & 0.6 & 2 & 0.1 & 0.3 \\
\hline Psocoptera & 0 & 0.0 & 0 & 0.0 & 0.0 & 5 & 0.6 & 8 & 0.6 & 0.6 \\
\hline Symphyla & 0 & 0.0 & 0 & 0.0 & 0.0 & 3 & 0.4 & 3 & 0.2 & 0.3 \\
\hline Trichoptera & 0 & 0.0 & 0 & 0.0 & 0.0 & 3 & 0.4 & 3 & 0.2 & 0.3 \\
\hline Trichoptera's larvae & 0 & 0.0 & 0 & 0.0 & 0.0 & 3 & 0.4 & 2 & 0.1 & 0.2 \\
\hline Thysanoptera & 0 & 0.0 & 0 & 0.0 & 0.0 & 6 & 0.9 & 3 & 0.2 & 0.5 \\
\hline Thysanura & 0 & 0.0 & 0 & 0.0 & 0.0 & 6 & 0.9 & 3 & 0.2 & 0.5 \\
\hline
\end{tabular}

*Average values obtained by 10 replicates.

Formicidae, followed by Diptera and Coleoptera were the predominant taxonomic groups (Table 1). Their individual relative density were greater than or equal to $3 \%$ in both areas, at least in one of the climatic seasons and for the average of the two climatic seasons. The sum of the relative density of these three groups was $59 \%$ and $72 \%$ in the areas of ISF and LSF in the wet season, respectively, and $81 \%$ and $87 \%$ in the areas of ISF and LSF in the dry season, respectively. The relative density of Formicidae and Coleoptera tended to decrease, while the relative density of Diptera tended to increase with the development of forest succession.

FLORESTA, Curitiba, PR, v. 51, n. 2, p. 429-438, abril/jun 2021.

Toledo, L. O. et.al.

ISSN eletrônico 1982-4688

DOI: $10.5380 /$ rf.v51 i2. 69413 
The values of total density, total richness, and mean richness were higher in the LSF area, regardless of the climatic season (Table 2). In contrast, the ISF area presented higher values of evenness, in both climatic seasons. These both patterns of influence of successional stage on the soil fauna community were obtained in both the presence and absence of Formicidae.

Table 2. Total density (D, individuals $\mathrm{m}^{-2}$ ), total richness $(\mathrm{S})$, mean richness (Sm), evenness (U, Pielou index), and diversity (H', Shannon index) (based on the sum of individuals extracted from the leaf litter layer and topsoil), in the presence and absence of Formicidae, in intermediate- and late-successional areas of Submountainous Seasonal Semideciduous Forest (ISF and LSF, respectively) in the wet and dry seasons in Pinheiral, Rio de Janeiro, Brazil*.

Tabela 2. Densidade total (D, indivíduos $\mathrm{m}^{-2}$ ), riqueza total $(\mathrm{S})$, riqueza média $(\mathrm{Sm})$, uniformidade (U, índice de Pielou) e diversidade (índice de Shannon) (com base na soma de indivíduos extraídos da camada de serapilheira e do solo superficial), na presença e ausência de Formicidae, em áreas de Floresta Estacional Semidecidual Submontana em estágios sucessionais intermediário e avançado (ISF and LSF, respectivamente) nas estações chuvosa e seca em Pinheiral, Rio de Janeiro, Brasil*.

\begin{tabular}{|c|c|c|c|c|c|c|c|c|c|c|}
\hline \multirow[t]{2}{*}{ Area/climatic season } & D & $\mathbf{S}$ & Sm & $\mathbf{U}$ & H' & D & $\mathbf{S}$ & Sm & $\mathbf{U}$ & H' \\
\hline & \multicolumn{5}{|c|}{ Presence of Formicidae } & \multicolumn{5}{|c|}{ Absence of Formicidae } \\
\hline ISF/Wet & 248 & 17 & 6 & 0.64 & 2.63 & 114 & 16 & 5 & 0.89 & 3.57 \\
\hline LSF/Wet & 752 & 33 & 15 & 0.56 & 2.80 & 320 & 32 & 14 & 0.86 & 4.32 \\
\hline ISF/Dry & 357 & 16 & 7 & 0.60 & 2.40 & 194 & 15 & 6 & 0.66 & 2.59 \\
\hline LSF/Dry & 1,373 & 31 & 13 & 0.42 & 2.09 & 888 & 30 & 12 & 0.37 & 1.79 \\
\hline
\end{tabular}

There was no clear pattern regarding the influence of the successional stage on the diversity of the soil fauna community, when considering the presence or absence of Formicidae (Table 2). However, the PCA plot indicated that the LSF area was associated with greater values of diversity as well as total density, total richness, mean richness, and density of all of the soil fauna taxonomic groups, in the wet or dry season (Figure 2a).

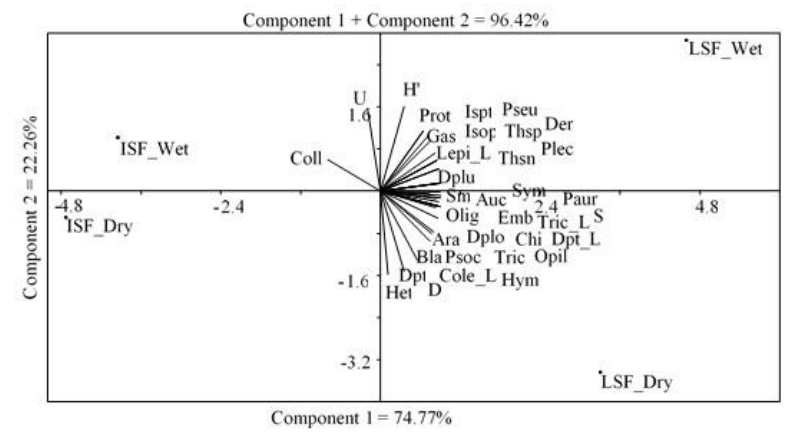

(a)

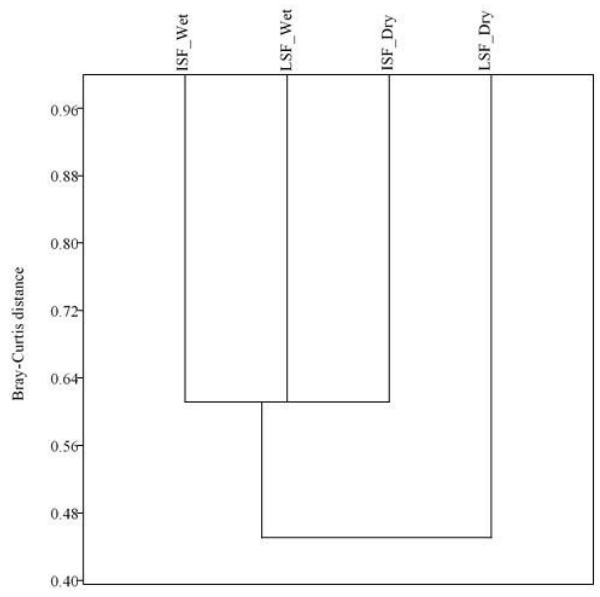

(b)

Figure 2. Principal component analysis (a) and hierarchical cluster analysis (b) for the soil fauna community attributes (based on the sum of individuals extracted from the leaf litter layer and topsoil), in the absence of Formicidae, in intermediate-successional (ISF) and late-successional (LSF) areas of Submountainous Seasonal Semideciduous Forest in the wet and dry seasons in Pinheiral, Rio de Janeiro, Brazil. D: total density; S: total richness; Sm: mean richness; U: evenness; H': diversity; Ara: Araneae; Auc: Auchenorrhyncha; Bla: Blattaria; Chi: Chilopoda; Cole: Coleoptera; Coll: Collembola; Der: Dermaptera; Dplo: Diplopoda; Dplu: Diplura; Dpt: Diptera; Emb: Embioptera; Gas: Gastropoda; Het: Heteroptera; Hym: Hymenoptera; Isop: Isopoda; Ispt: Isoptera; Col_L: Coleoptera's larvae; Dpt_L: Diptera's larvae; Lepi_L: Lepidoptera's larvae; Tric_L: Trichoptera's larvae; Olig: Oligochaeta; Opil: Opilionida; Paur: Pauropoda; Plec: Plecoptera; Prot: Protura; Pseu: Pseudoscorpionida; Psoc: Psocoptera; Sym: Symphyla; Tric: Trichoptera; Thsp: Thysanoptera; Thsn: Thysanura.

Figura 2. Análise de componentes principais (a) e análise de agrupamento hierárquico para atributos da comunidade da fauna do solo (com base na soma de indivíduos extraídos da camada de serapilheira e do solo superficial), na ausência de Formicidae, em áreas de Floresta Estacional Semidecidual Submontana em estágios sucessionais intermediário e avançado (ISF and LSF, respectivamente) nas estações chuvosa e seca em Pinheiral, Rio de

FLORESTA, Curitiba, PR, v. 51, n. 2, p. 429-438, abril/jun 2021.

Toledo, L. O. et.al.

ISSN eletrônico 1982-4688

DOI: $10.5380 /$ rf.v51 i2. 69413 
Janeiro, Brasil. D: densidade total; S: riqueza total; Sm: riqueza média; U: uniformidade; H': diversidade; Ara: Araneae; Auc: Auchenorrhyncha; Bla: Blattaria; Chi: Chilopoda; Cole: Coleoptera; Coll: Collembola; Der: Dermaptera; Dplo: Diplopoda; Dplu: Diplura; Dpt: Diptera; Emb: Embioptera; Gas: Gastropoda; Het: Heteroptera; Hym: Hymenoptera; Isop: Isopoda; Ispt: Isoptera; Col_L: Coleoptera's larvae; Dpt_L: Diptera's larvae; Lepi_L: Lepidoptera's larvae; Tric_L: Trichoptera's larvae; Olig: Oligochaeta; Opil: Opilionida; Paur: Pauropoda; Plec: Plecoptera; Prot: Protura; Pseu: Pseudoscorpionida; Psoc: Psocoptera; Sym: Symphyla; Tric: Trichoptera; Thsp: Thysanoptera; Thsn: Thysanura.

The exception occurred for Collembola and evenness, whose association was observed for the ISF area, in the wet season (Figure 2a). The attributes Orthoptera's density, total density of individuals in the litter layer and total density of individuals in topsoil did not present correlation coefficient above $0.70 \%$ with the principal component 1 or principal component 2.

The PCA allowed individualizing the areas in each season according to their relationship with principal component 1 and principal component 2. The LSF area in both wet and dry seasons was located on the right side of principal component 1 (positive eigenvectors), which explained $74.77 \%$ of the data variance (Figure 2a). The ISF area in the wet and dry seasons was located on the left side of the same principal component (negative eigenvectors). In relation to the principal component 2, which explained $22.26 \%$ of the data variance, the ISF and LSF areas in the wet season were both located on the upper part of this component (positive eigenvectors). On the other hand, the ISF and LSF areas in the dry season were grouped on the bottom part of the component 2 (negative eigenvectors). The two principal components explained together $96.24 \%$ of the total variance.

The dendrogram obtained by hierarchical cluster analysis showed two main clusters (Figure 2b). The LSF area in the dry season stood out by a distance of approximately $45 \%$ from the grouping formed by ISF and LSF in the wet season as well as ISF in the dry season. The distance of similarity that linked this group was approximately $60 \%$.

In the absence of Formicidae, Araneae, Collembola, Coleoptera, Diptera, Isoptera, and Orthoptera predominated (relative density greater than or equal to 3\%) in the soil fauna community. Thus, the relative density of Collembola, Orthoptera, and Araneae tended to be higher in the ISF area, while the opposite pattern, ie higher relative density values in the LSF area, were observed for Diptera and "Others", regardless of the climatic season (Figure 3a). There was no well-defined pattern for Isoptera and Coleoptera relative density variation as a function of the successional stage.

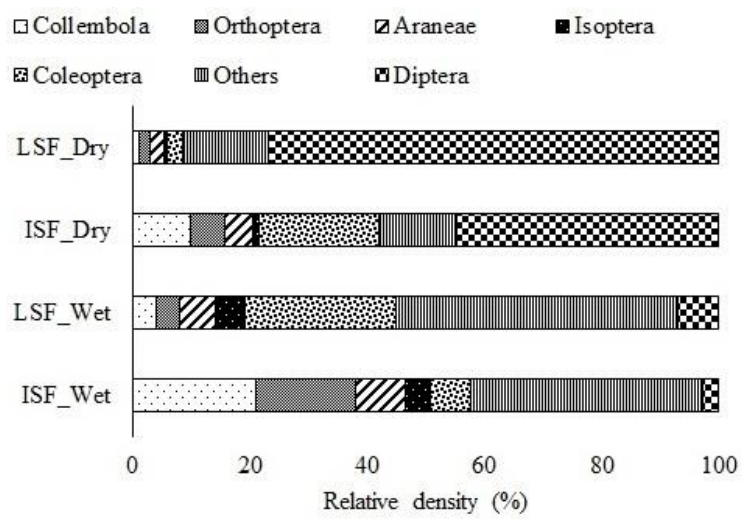

(a)

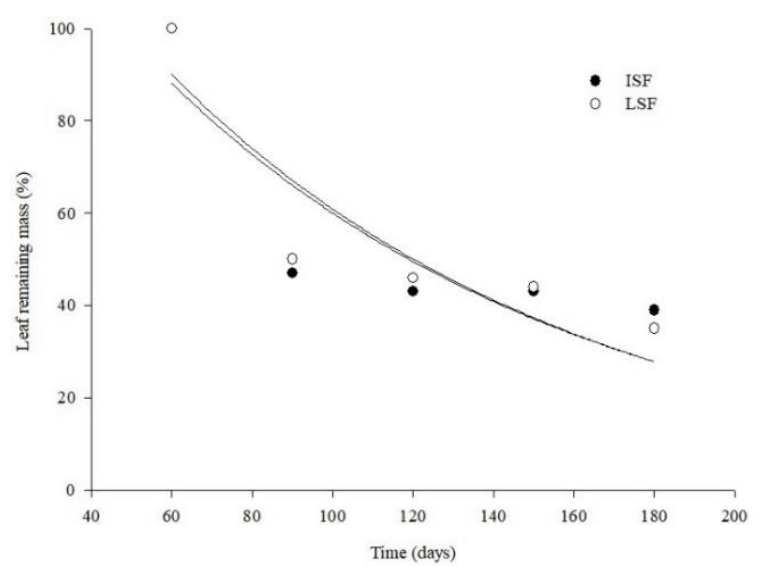

(b)

Figure 3. Relative density (\%) of the predominant soil fauna taxonomic groups and "Others" (based on the sum of individuals extracted from the leaf litter layer and topsoil), in the absence of Formicidae (a), and leaf litter mass loss over time (b), in intermediate- and late-successional areas of Submountainous Seasonal Semideciduous Forest (ISF and LSF, respectively) in the wet and dry seasons in Pinheiral, Rio de Janeiro, Brazil.

Figura 3. Densidade relativa (\%) dos grupos taxonômicos predominantes da fauna do solo e "Outros" (com base na soma de indivíduos extraídos da camada de serapilheira e do solo superficial), na ausência de Formicidae (a), e perda de massa da serapilheira foliar ao longo do tempo (b), em áreas de Floresta Estacional Semidecidual Submontana em estágios sucessionais intermediário e avançado (ISF and LSF, respectivamente) nas estações chuvosa e seca em Pinheiral, Rio de Janeiro, Brasil.

The total relative density of individuals was higher in the leaf litter layer in the area of LSF, in the wet

FLORESTA, Curitiba, PR, v. 51, n. 2, p. 429-438, abril/jun 2021.

Toledo, L. O. et.al.

ISSN eletrônico 1982-4688

DOI: $10.5380 /$ rf.v51 i2. 69413 
(69\% of total community) and dry seasons (59\%), and in the area of ISF in the wet season (76\%), when compared to the topsoil $(31 \%, 41 \%$, and $24 \%$, respectively). However, we captured $95 \%$ of the individuals from the topsoil, in the area of ISF in the dry season, in relation to the leaf litter layer ( $5 \%$ of the community). Thus, the density of individuals extracted from the litter layer ranged from 1.43 (dry season) to 2.22 (rainy season) times higher in the LSF area, and was 3.17 times higher in the ISF area, in comparison with the topsoil. The opposite pattern occurred in the LSF area in the dry season, in which the density of individuals extracted from the topsoil was 19 times higher than the litter layer.

\section{Leaf litter decomposition}

At the end of the experiment (day 180), only $37 \%$ and $32 \%$ of leaf litter remained in the litterbags collected from ISF and LSF, respectively. In other words, $63 \%$ and $68 \%$ of leaf litter decomposed respectively in ISF and LSF (Figure 3b).

Leaf litter decay constants were 0.0096 and $0.0098 \mathrm{~g} \mathrm{~g}^{-1}$ day ${ }^{-1}$; and the half-life, 72 and 71 days in ISF and LSF, respectively. The leaf litter decay function for ISF is given by $f=156.7723 \times \mathrm{e}^{-0.0096 t}\left(R^{2}=0.7316\right)$; and for LSF, $f=161.9592 \times \mathrm{e}^{-0.0098 t}\left(R^{2}=0.8095\right)$.

\section{DISCUSSION}

\section{Soil fauna}

The late-successional forest area presented greater soil fauna richness, diversity, and density of practically all of the taxonomic groups, in comparison to the intermediate-successional area. The favoring of the soil fauna community along the forest succession was demonstrated by previous studies that were conducted in areas of Submountainous Seasonal Semideciduous Forest (MACHADO et al., 2015b; CAMARA et al., 2018b) and Submountainous Dense Ombrophilous Forest (FERREIRA et al., 2018). Greater soil fauna richness is probably related to the more complex forest structure of late-successional areas. In such forests, the trees community often have higher biomass and richness, leaf litter production is more intense and diverse (MACHADO et al., 2015a; CAMARA et al., 2018a), and canopy density is higher.

These factors lead to decreased incidence of solar radiation at ground level and milder temperatures in the soil environment, thus promoting microclimate conditions best suited to the reproduction and survival of a wide variety of soil fauna organisms (FERREIRA et al., 2018). Moreover, the higher production of leaf litter in the late-successional forest area contributes to high input of $\mathrm{N}, \mathrm{P}, \mathrm{K}, \mathrm{Ca}, \mathrm{Mg}, \mathrm{Cu}, \mathrm{Fe}, \mathrm{Mn}$, and $\mathrm{Zn}$ through litter, compared with the intermediate-successional area (TOLEDO et al., 2002). Thus, the availability of nutrient-rich food sources for the soil fauna community is greater in late-successional forests (CAMARA et al., 2018a), which demonstrated greater soil quality in this area when compared to the intermediate-successional forest area.

Formicidae was the most abundant taxonomic group in both areas, followed by Diptera and Coleoptera. The predominance of Formicidae is due to the abundance and diversity of these social animals (SABU et al., 2011). It is estimated that the relative abundance/density of ants in soil fauna is even higher than the perceived, as most of these individuals remain inside the nest and thus are not sampled. Ants build subterranean galleries that increase aeration, water infiltration, and root distribution in the soil and play a role in nutrient cycling by regulating the population of soil microarthropods that feed on decomposing microorganisms. Furthermore, their richness is positively correlated with the complexity of the structure of the environment (BIHN et al., 2010). Coleoptera and Diptera are groups that have a varied functional spectrum, as they include species that act as pollinators, seed dispersers, predators, decomposers (TRIPLEHORN; JONNSON, 2011), and food source for predators, contributing to the richness of the soil fauna community as a whole.

The relative density of Araneae, Collembola, and Orthoptera decreased, while the relative density of Diptera increased along the development of forest succession. In previous studies, the influence of the stage of forest succession on the relative density of these groups widely varied. As the process of tropical forest succession developed, the relative density of Collembola (represented by the subgroups of Entomobryomorpha, Poduromorpha, and Symphypleona), Orthoptera, and Diptera could increase or decrease (CAMARA et al., 2012; MACHADO et al., 2015b; CAMARA et al., 2018; FERREIRA et al., 2018). The divergence of these results may be a function of differences among the studies in terms of phytophysiognomy and method of extraction of the soil fauna organisms.

Machado et al. (2015b) and Camara et al. (2018) studied the soil fauna community in areas of Seasonal Semideciduous Forest by extracting the soil fauna organisms in pitfall traps. Camara et al. (2012) also employed pitfall traps, while Ferreira et al. (2018) extracted the soil organisms in topsoil blocks, and both of them conducted their experiments in areas of Dense Ombrophilous Forest. Pitfall traps are the most suitable extraction method for

FLORESTA, Curitiba, PR, v. 51, n. 2, p. 429-438, abril/jun 2021.

Toledo, L. O. et.al. 
Diptera and Orthoptera (SABU et al., 2011). Thus, the modified Berlese-Tüllgren funnels employed in the current study, which is the best method for Collembola (SABU et al., 2011), might have led to an underestimation of Diptera's relative density.

In general, the two patterns observed for the soil fauna attributes occurred regardless the presence or absence of Formicidae. The first pattern for the soil fauna community refers to the higher values of total density, richness, and diversity in the late-successional area, whereas the second patter refers to the higher values of evenness in the intermediate-successional area, both of them in the presence or absence of Formicidae. The second patter occurred due to the higher relative density of the predominant taxonomic groups in the late-successional area, in the presence of Formicidae (the latter group, Coleoptera, and Diptera), and in the absence of Formicidae (Araneae, Coleoptera, Collembola, Diptera, Isoptera, and Orthoptera), in comparison to the intermediatesuccessional area.

The PCA plot showed marked differences in soil fauna attributes between the studied areas in each climatic season, as they were located on opposite sides of both principal component 1 and principal component 2 . Moreover, the similarity between the late-successional area in the dry season and the other conditions, which included the grouping formed by the gathering between the intermediate-successional area in both climatic seasons and the late-successional area in the wet season, was considered low $(<50 \%)$. This result suggested that the influence of the successional stage on the attributes of the soil fauna community was enhanced by the climate season.

The striking differences between the areas within each climate season regarding the vertical distribution of soil fauna corroborated this pattern. In fact, the pattern of higher total relative density of individuals in the leaf litter layer in the area of late-successional area, in both climatic seasons, and in the area of intermediatesuccessional area in the wet season changed completely when compared to the intermediate-successional area in the dry season, in which the density of individuals extracted from the topsoil was much higher than the observed in the litter layer. In early and intermediate-successional forest areas, the tree community structure and litterfall are both lower (MACHADO et al., 2015a), which results in higher incidence of solar radiation in the leaf litter layer, leading to high fluctuations in temperature and water content (MALTA et al., 2012), when compared to latesuccessional forest areas. Thus, the organisms are forced to migrate from litter layer to the topsoil in search of more favorable micro-climatic conditions, in areas with less advanced stage of succession.

\section{Leaf litter decomposition}

The leaf litter decay constants for ISF and LSF were very similar, as shown by the overlap of decay curves. This result was probably due to the rapid stabilization of microclimatic conditions and activity of decomposers (VENDRAMI et al., 2012). Decay rates observed in this study were higher than those reported for areas of Semideciduous Forests (Table 3). The half-life of leaf litter in Semideciduous Forests at early- and intermediate-successional stages is about twice that in late successional stages.

Table 3. Decay constant (k) and half-life $\left(\mathrm{t}_{1 / 2}\right)$ of leaf litter in early-, intermediate-, and late-successional in areas of Seasonal Semideciduous Forests in Brazil.

Tabela 3. Constante de decomposição $(\mathrm{k})$ e tempo de meia-vida $\left(\mathrm{t}_{1 / 2}\right)$ da serapilheira foliar em áreas de Floresta Estacional Semidecidual nos estágios sucessionais inicial, intermediário e avançado no Brasil.

\begin{tabular}{|c|c|c|c|c|}
\hline Successional stage & Site & $k\left(g^{-1}\right.$ day $)$ & $\mathbf{t}_{1 / 2}$ (days) & Reference \\
\hline \multirow[t]{4}{*}{ Early } & Além Paraíba, MG & 0.0026 & 266 & Cunha Neto et al. (2013) \\
\hline & Pinheiral, RJ & 0.0044 & 154 & Menezes et al. (2010) \\
\hline & & 0.0022 & 315 & Machado et al. (2015a) \\
\hline & & Mean & 245 & \\
\hline \multirow[t]{6}{*}{ Intermediate } & Pinheiral, RJ & 0.0038 & 182 & Menezes et al. (2010) \\
\hline & & 0.0033 & 217 & Machado et al. (2015a) \\
\hline & & 0.0096 & 72 & This study \\
\hline & Vitória da Conquista, BA & 0.0023 & 301 & Silva et al. (2014) \\
\hline & & 0.0016 & 433 & Pinto et al. (2016) \\
\hline & & Mean & 241 & \\
\hline \multirow[t]{4}{*}{ Late } & Pinheiral, RJ & 0.0064 & 108 & Menezes et al. (2010) \\
\hline & & 0.0046 & 151 & Machado et al. (2015a) \\
\hline & & 0.0098 & 71 & This study \\
\hline & & Mean & 110 & \\
\hline
\end{tabular}

The changes that occur in soil conditions $(\mathrm{pH}$, nutrient availability, water content), leaf litter quality (content of $\mathrm{N}$, polyphenols, cellulose, lignin and C/N ratio) (PINTO et al., 2016), and interaction between soil

FLORESTA, Curitiba, PR, v. 51, n. 2, p. 429-438, abril/jun 2021.

Toledo, L. O. et.al.

ISSN eletrônico 1982-4688 
fauna and decomposing microorganisms (GRANDY et al., 2016) throughout the natural succession of forests contribute to litter decomposition. The litter decomposition is faster in areas in late succession due to the increased leaf litter nutrient concentrations (Table 3), which benefits decomposers and soil fauna that rely on leaf litter as a food source, when compared to earlier successional stages (MACHADO et al., 2015a).

Some factors hinder comparison of the results of this study with those of previous studies, even with those that were carried out in areas of the same forest type and successional stage. This is due to differences in the criteria used to classify successional stages. Depending on the criteria, some fragments grouped into a single successional stage in one study may be classified into different stages in another (VENDRAMI et al., 2012). Furthermore, the history of land use, which determines the type and frequency of the disturbance; soil type; size and shape of forest fragments; and type of surrounding matrix influence the microclimatic soil conditions and, consequently, interfere with the decomposition process. Variations in the amount of leaf litter placed in litterbags, the type of litterbag, and the treatment of litter can also affect the results.

In the present study, $30 \mathrm{~g}$ of recently collected leaves were air-dried at room temperature and placed in 4 mm mesh litterbags $(25 \times 25 \mathrm{~cm})$. Menezes et al. (2010), Cunha Neto et al. (2013), and Machado et al. (2015a) used 4, 4, and $2 \mathrm{~mm}$ mesh litterbags $(25 \times 25 \mathrm{~cm})$, respectively, and loaded them with $10 \mathrm{~g}$ of newly fallen, airdried leaves. Silva et al. (2014) and Pinto et al. (2016), however, used $10 \mathrm{~g}$ of newly fallen leaves that had been previously oven-dried to constant weight at $65^{\circ} \mathrm{C}$ in $1 \mathrm{~mm}$ mesh litterbags $(20 \times 20 \mathrm{~cm})$.

The amount of leaves may influence the microclimate formed within the litterbag. In addition, air-dried and oven-dried litter differ in palatability for decomposers and soil fauna. Another aspect to be considered is the mesh size of litterbags. This parameter can have a decisive impact on the participation of soil fauna in the decomposition process. Soil fauna are grouped into micro-, meso-, and macrofauna according to the body diameter (SWIFT et al., 1979). The small mesh size used by Silva et al. (2014) and Pinto et al. (2016) prevented the entry of respectively some mesofauna $(0.010-2 \mathrm{~mm})$ and macrofauna $(>2 \mathrm{~mm})$ into the litterbags. The litterbag used by Cunha Neto et al. (2013) completely prevented the entry of macrofauna. In the studies of Menezes et al. (2010) and Machado et al. (2015a), both mesofauna and macrofauna were not excluded. Without meso- and macrofauna, the decomposition rate is highly reduced (LECERF, 2017).

These limitations demonstrate the need for further studies on nutrient cycling in Seasonal Semideciduous forests. The relationship of the structure and composition of soil fauna and leaf litter decomposition with successional stage remains to be determined. Collection and evaluation methods should be standardized to allow inferences to be made from the results of different studies.

\section{CONCLUSIONS}

- The soil fauna community in the late-successional area was associated with higher values of richness, diversity, total density, and density of taxonomic groups, whereas higher values of evenness occurred in the intermediate-successional area of Submountainous Seasonal Semideciduous Forest.

- The principal component analysis, hierarchical cluster analysis, and the vertical distribution of the soil fauna community between the litter layer and the topsoil indicated that the influence of the successional stage on the attributes of the soil fauna community was enhanced by the climatic season.

- The process of leaf litter decomposition was almost identical in the intermediate-successional and the late-successional fragment of Submountainous Seasonal Semideciduous Forest.

\section{REFERENCES}

ALVARES, C. A.; STAPE, J. L.; SENTELHAS, P. C.; GONÇALVES, J. L. M.; SPAROVEK, G. Köppen's climate classification map for Brazil. Meteorologische Zeitschrift, Stuttgart, v. 22, n. 6, p. 711 - 728, 2013.

BIHN, J. H.; GEBAUER, G.; BRANDL, R. Loss of functional diversity of ant assemblages in secondary tropical forests. Ecology, Washington, v. 91, n. 3, p. 782 - 792, 2010.

BRASIL. Resolução CONAMA nº 06, de 04 de maio de 1994. Estabelece definições e parâmetros mensuráveis para análise de sucessão ecológica da Mata Atlântica no Rio de Janeiro. Diário Oficial da União, Brasília, DF, quatro de maio de 1994. Available from: <http://www.mma.gov.br/port/conama/legiabre.cfm?codlegi=147>. Accessed on: 02 dec. 2017.

CAMARA, R.; SILVA, V. D.; DELAQUA, G. C. G.; LISBÔA, C. P.; VILLELA, D. M. Relação entre sucessão secundária, solo e serapilheira em uma Reserva Biológica no Estado do Rio de Janeiro, Brasil. Ciência Florestal, Santa Maria, v. 28, n. 2, p. 674 - 686, 2018a.

FLORESTA, Curitiba, PR, v. 51, n. 2, p. 429-438, abril/jun 2021.

Toledo, L. O. et.al.

ISSN eletrônico 1982-4688

DOI: $10.5380 /$ rf.v51 i2. 69413 
CAMARA, R.; SANTOS, G. L.; PEREIRA, M. G.; SILVA, C. F.; SILVA, V. F. V.; SILVA, R. M. Effects of natural Atlantic Forest regeneration on soil fauna, Brazil. Floresta e Ambiente, Seropédica, v. 25, n. 1, e20160017, 2018 b.

CORREIA, M. E. F.; ANDRADE, A. G. Formação de serapilheira e ciclagem de nutrientes. In: SANTOS, G. A.; SILVA, L. S.; CANELLAS, L. P.; CAMARGO, F. A. O. Fundamentos da matéria orgânica do solo: ecossistemas tropicais e subtropicais. Porto Alegre: Metrópole, 2 ed. 2008, 654 p.

CUNHA NETO, F. V.; LELES; P. S. S.; PEREIRA, M. G.; BELlUMATH, V. G. H.; ALONSO, J. M. Acúmulo e decomposição da serapilheira em quatro formações florestais. Ciência Florestal, Santa Maria, v. 23, n. 3, p. 379 -387, 2013.

FERREIRA, C. R.; CORREIA, M. E. F.; CAMARA, R.; RESENDE, A. S.; ANJOS, L. H. C.; PEREIRA, M. G. Soil fauna changes across Atlantic Forest succession. Comunicata Scientiae, Bom Jesus, v. 9, n. 2, p. 162 - 174, 2018.

GARAY, I. Relations entre l'hétérogénéité des litières et l'órganisation des peuplements d'arthropodes édaphiques. Publications du Laboratoire de Zoologie, Paris, n. 35, p. 191, 1989.

GRANDY, A. S.; WIEDER, W. R.; WICKINGS, K.; KYKER-SNOWMAN, E. Beyond microbes: Are fauna the next frontier in soil biogeochemical models? Soil Biology \& Biochemistry, Oxford, n. 102, p. 40 - 44, 2016.

LECERF, A. Methods for estimating the effect of litterbag mesh size on decomposition. Ecological Modelling, Oxford, v. 362, p. $65-68,2017$.

MACHADO, D. L.; PEREIRA, M. G.; CORREIA, M. E. F.; DINIZ, A. R.; SANTOS, L. L.; MENEZES, C. E. G. Ciclagem de nutrientes em diferentes estágios sucessionais da Mata Atlântica na bacia do Rio Paraíba do Sul, RJ. Bioscience Journal, Uberlândia, v. 31, n. 4, p. 1222 - 1237, 2015a.

MACHADO, D. L.; PEREIRA, M. G.; CORREIA, M. E. F.; DINIZ, A. R.; MENEZES, C. E. G. Fauna edáfica na dinâmica sucessional da Mata Atlântica em Floresta Estacional Semidecidual na bacia do Rio Paraíba do Sul - RJ. Ciência Florestal, Santa Maria, v. 25, n. 1, p. 91 - 106, 2015 b.

MALTA, J. A.; SOUZA, O, H. T. R.; MELO E SOUZA, R. Fitogeografia e regeneração natural em florestas urbanas de São Cristóvão/SE-Brasil. Investigaciones Geográficas, Cidade do México, n. 77, p. 48 - 62, 2012.

MENEZES, C. E. G.; PEREIRA, M. G.; CORREIA, M. E. F.; ANJOS, L. H. C.; PAULA, R. R.; SOUZA, M. E. Aporte e decomposição da serapilheira e produção de biomassa radicular em florestas com diferentes estágios sucessionais em Pinheiral, RJ. Ciência Florestal, Santa Maria, v. 20, n. 3, p. 439 - 452, 2010.

ODUM, E. P. Ecologia. Rio de Janeiro: Editora Guanabara Koogan, 1988, 434 p.

PINTO, H. C. A.; BARRETO, P. A. B.; GAMA-RODRIGUES, E. M.; OLIVEIRA, F. G. R. B.; PAULA, A.; AMARAL, A. R. Decomposição da serapilheira foliar de floresta nativa e plantios de Pterogyne nitens e Eucalyptus urophylla no sudoeste da Bahia. Ciência Florestal, Santa Maria, v. 26, n. 4, p. 1141 - 1153, 2016.

REZENDE, C. P., CANTARUTTI, R. B.; BRAGA, J. M.; GOMIDE, J. A.; PEREIRA, J. M.; FERREIRA, E. TARRÉ, R.; MACEDO, R.; ALVES, B. J. R.; URQUIAGA, S.; CADISCH, G.; GILLER, K. E.; BODDEY, R. M. Litter deposition and disappearance in Brachiaria pastures in the Atlantic Forest region of the south of Bahia, Brazil. Nutrient Cycling in Agroecosystems, Dordrecht, v. 54, n. 2, p. 99 - 112, 1999.

SABU, T. K.; SHIJU, R. T.; VINOD, K. V.; NITHYA, S. A. A comparison of the pitfall trap, Winkler extractor and Berlese funnel for sampling ground-dwelling arthropods in Tropical Montane Cloud Forests. Journal of Insect Science, Oxford, v. 11, p. 1 - 19, 2011.

SILVA, H. F.; BARRETO, P. A. B.; SOUSA, G. T. O.; AZEVEDO, G. B.; GAMA-RODRIGUES, E. M.; OLIVEIRA, F. G. R. B. Decomposição de serapilheira foliar em três sistemas florestais no Sudoeste da Bahia. Revista Brasileira de Biociências, Porto Alegre, v. 12, n. 3, p. 164 - 172, 2014.

SWIFT, M. J.; HEAL, O. W.; ANDERSON, J. M. Decomposition in terrestrial ecosystems. Oxford: Blackwell Scientific Publications, 1979, 372 p.

THOMAS, R. J.; ASAKAWA, N. M. Decomposition of leaf litter from tropical forage grasses and legumes. Soil Biology and Biochemistry, Leicestershire, v. 25, n. 10, p. 1351 - 1361, 1993.

TOLEDO L. O.; PEREIRA, M. G.; MENEZES, C. E. G. Produção de serapilheira e transferência de nutrientes em florestas secundárias localizadas na região de Pinheiral, RJ. Ciência Florestal, Santa Maria, v. 12, n. 2, p. 9 - $16,2002$. TRIPLEHORN, C. A.; JOHNSON, N. F. Estudo dos Insetos. São Paulo: Cengage Learning, 7 ed. 2011, 816 p.

VENDRAMI, J. L.; JURINITZ, C. F.; CASTANHO, C. T.; LORENZO, L.; OLIVEIRA, A. A. Litterfall and leaf decomposition in forest fragments under different successional phases on the Atlantic Plateau of the state of São Paulo, Brazil. Biota Neotropica, Campinas, v. 12, n. 3, p. 136 - 143, 2012.

FLORESTA, Curitiba, PR, v. 51, n. 2, p. 429-438, abril/jun 2021.

Toledo, L. O. et.al. 